\title{
A Guanidinium Ion-Based Anion- and Solvent Polarity-Controllable Molecular Switch
}

2009

Vol. 11, No. 3

$613-616$

\section{Tzu-Chiun Lin, ${ }^{\dagger}$ Chien-Chen Lai, ${ }^{\ddagger}$ and Sheng-Hsien Chiu ${ }^{\star, \dagger}$ \\ Department of Chemistry, National Taiwan University, No. 1, Sec. 4, Roosevelt Road, Taipei, Taiwan, 10617, R.O.C., and Institute of Molecular Biology, National Chung Hsing University and Department of Medical Genetics, China Medical University \\ Hospital, Taichung, Taiwan, R.O.C.}

shchiu@ntu.edu.tw

Received November 17, 2008

\section{ABSTRACT}

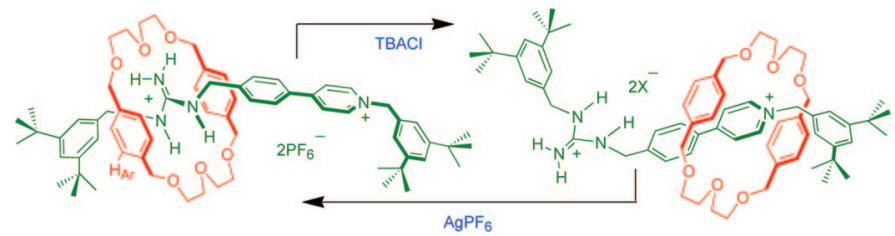

The macrocycle bis-p-xylyl[26]crown-6 (BPX26C6) is capable of complexing guanidinium ions in a [2]pseudorotaxane-like manner in solution. A corresponding molecular switch can be operated through changes in solvent polarity or the addition and removal of halogen and acetate anions.

Arginine plays an important role in the reception pockets of many enzymes, where its guanidinium residue acts as a recognition unit for anionic substrates. ${ }^{1}$ Taking this cue from Nature, several artificial anion receptors have been prepared

National Taiwan University.

₹ China Medical University Hospital.

(1) (a) Riordan, J. F. Mol. Cell. Biochem. 1979, 26, 71-92. (b) Shimoni, L.; Glusker, J. P. Protein Sci. 1995, 4, 65-74.

(2) (a) Houk, R. J. T.; Tobey, S. L.; Anslyn, E. V. Top. Curr. Chem. 2005, 255, 199-229. (b) Blondeau, P.; Segura, M.; Perez-Fernandez, R.; De Mendoza, J. Chem. Soc. Rev. 2007, 36, 198-210. (c) Gale, P. A.; GarciaGarrido, S. E.; Garric, J. Chem. Soc. Rev. 2008, 37, 151-190.

(3) (a) Armaroli, N.; Balzani, V.; Collin, J.-P; Gaviña, P.; Sauvage, J.P.; Ventura, B. J. Am. Chem. Soc. 1999, 121, 4397-4408. (b) Altieri, A.; Gatti, F. G.; Kay, E. R.; Leigh, D. A.; Martel, D.; Paolucci, F.; Slawin, A. M. Z.; Wong, J. K. Y. J. Am. Chem. Soc. 2003, 125, 8644-8654. (c) Jeon, W. S.; Ziganshina, A. Y.; Lee, J. W.; Ko, Y. H.; Kang, J.-K.; Lee, C.; Kim, K. Angew. Chem., Int. Ed. 2003, 42, 4097-4100. (d) Tseng, H.R.; Vignon, S. A.; Celestre, P. C.; Perkins, J.; Jeppesen, J. O.; Di Fabio, A.; Ballardini, R.; Gandolfi, M. T.; Venturi, M.; Balzani, V.; Stoddart, J. F. Chem.-Eur. J. 2004, 10, 155-172.

(4) (a) Ballardini, R.; Balzani, V.; Clemente-Leon, M.; Credi, A.; Gandolfi, M. T.; Ishow, E.; Perkins, J.; Stoddart, J. F.; Tseng, H.-R.; Wenger, S. J. Am. Chem. Soc. 2002, 124, 12786-12795. (b) Berna, J.; Leigh, D. A.; Lubomska, M.; Mendoza, S. M.; Perez, E. M.; Rudolf, P.; Teobaldi, G.; Zerbetto, F. Nat. Mater. 2005, 4, 704-710. (c) Saha, S.; Stoddart, J. F. Chem. Soc. Rev. 2007, 36, 77-92. (d) Pijper, D.; Jongejan, M. G. M.; Meetsma, A.; Feringa, B. L. J. Am. Chem. Soc. 2008, 130, 4541-4552. featuring guanidinium derivatives for the recognition of both spherical halide and Y-shaped carboxylate anions. ${ }^{2}$ Although electrons, ${ }^{3}$ photons, ${ }^{4}$ cations, ${ }^{5}$ and heat ${ }^{6}$ have all been used as external stimuli to control the operation of molecular switches, reports of anion-mediated interlocked switches are rare. ${ }^{7}$ In theory, an anion-controllable molecular switch could be constructed by interlocking the components of a [2]pseudorotaxane complex featuring a guanidinium ion-derived threadlike component because competition between external

(5) (a) Kaiser, G.; Jarrosson, T.; Otto, S.; Ng, Y.-F.; Bond, A. D.; Sanders, J. K. M. Angew. Chem., Int. Ed. 2004, 43, 1959-1962. (b) Huang, F.; Switek, K. A.; Gibson, H. W. Chem. Commun. 2005, 3655-3657. (c) Yen, M.-L.; Li, W.-S.; Lai, C.-C.; Chao, I.; Chiu, S.-H. Org. Lett. 2006, 8, 3223-3226.

(6) (a) Altieri, A.; Bottari, G.; Dehez, F.; Leigh, D. A.; Wong, J. K. Y.; Zerbetto, F. Angew. Chem., Int. Ed. 2003, 42, 2296-2300. (b) Jeong, K.S.; Chang, K.-J.; An, Y.-J. Chem. Commun. 2003, 12, 1450-1451. (c) Liu, Y.; Flood, A. H.; Stoddart, J. F. J. Am. Chem. Soc. 2004, 126, 9150-9151. (d) Chiang, P.-T; Cheng, P.-N.; Lin, C.-F.; Liu, Y.-H.; Lai, C.-C.; Peng, S.-M.; Chiu, S.-H. Chem.-Eur. J. 2006, 12, 865-876.

(7) (a) Montalti, M.; Prodi, L. Chem. Commun. 1998, 1461-1462. (b) Keaveney, C. M.; Leigh, D. A. Angew. Chem., Int. Ed. 2004, 43, 12221224. (c) Laursen, B. W.; Nygaard, S.; Jeppesen, J. O.; Stoddart, J. F. Org. Lett. 2004, 6, 4167-4170. (d) Lin, C.-F.; Lai, C.-C.; Liu, Y.-H.; Peng, S.M.; Chiu, S.-H. Chem.-Eur. J. 2007, 13, 4350-4355. (e) Huang, Y.-L.; Hung, W.-C.; Lai, C.-C.; Liu, Y.-H.; Peng, S.-M.; Chiu, S.-H. Angew. Chem., Int. Ed. 2007, 46, 6629-6633. 
anions and the macrocyclic component for the guanidinium ion recognition site would influence the location of the macrocycle. We are unaware of any such [2]pseudorotaxane complexes having been reported previously, possibly because most guanidinium salts are soluble only in polar solvents, which disfavors their hydrogen bonding with external hosts. In this paper, we report (i) that the macrocycle bis- $p$ xylyl[26]crown- $6^{8}$ (BPX26C6) forms [2]pseudorotaxane-like complexes with guanidinium ions in solution and (ii) that a corresponding molecular switch can be operated through changes in solvent polarity or through the addition and removal of halogen and acetate anions.

Previously, we reported that macrocycle 1 forms [2]pseudorotaxane complexes with diphenylurea derivatives in solution (Scheme 1). ${ }^{7 \mathrm{e}}$ Because guanidinium ions and

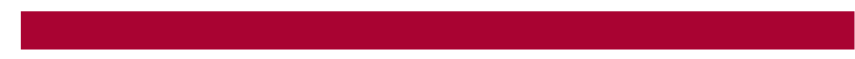

\section{Scheme 1}

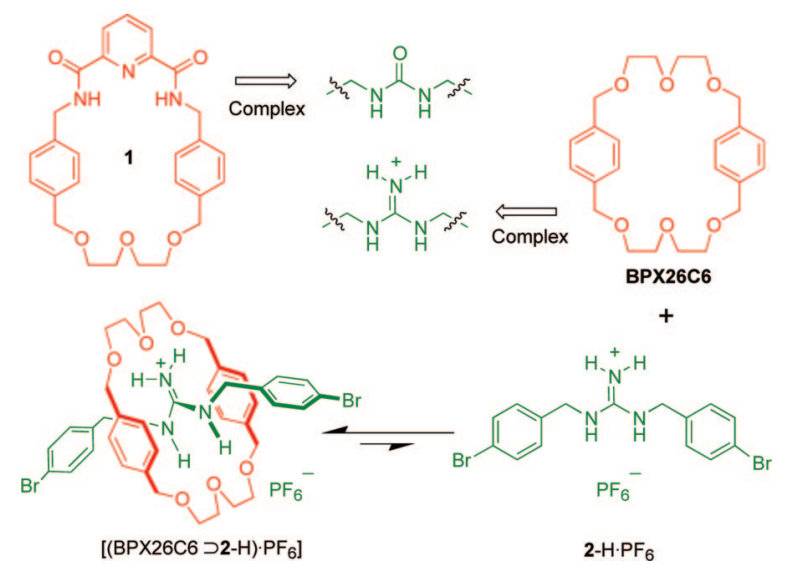

diphenylurea molecules both feature Y-shaped hydrogen bond donor units, we suspected that replacing the hydrogen bond-donating diamidopyridine motif (used to recognize the $\mathrm{C}=\mathrm{O}$ group of the urea unit) of macrocycle $\mathbf{1}$ into another hydrogen bond-receiving diethylene glycol unit would allow us to construct a macrocycle capable of forming complexes with guanidinium ions. Thus, we selected BPX26C6, which forms complexes with pyridinium and bipyridinium ions through $[\mathrm{C}-\mathrm{H} \cdots \mathrm{O}]$ hydrogen bonding and complimentary electrostatic aromatic stacking interactions, to test its ability to form complexes with planar cationic guanidinium ions.

We synthesized the threadlike guanidinium salt $2-\mathrm{H} \cdot \mathrm{PF}_{6}$ from the 4-bromobenzylamine $\mathbf{3}$ in five steps (Scheme 2). The reaction of the amine $\mathbf{3}$ and benzoyl isothiocyanate 4

(8) (a) Cheng, P.-N.; Lin, C.-F.; Liu, Y.-H.; Lai, C.-C.; Peng, S.-M.; Chiu, S.-H. Org. Lett. 2006, 8, 435-438. (b) Cheng, P.-N.; Huang, P.-Y.; Li, W.-S.; Ueng, S.-H.; Hung, W.-C.; Liu, Y.-H.; Lai, C.-C.; Peng, S.-M.; Chao, Ito; Chiu, S.-H. J. Org. Chem. 2006, 71, 2373-2383. (c) Chen, N.C.; Huang, P.-Y.; Lai, C.-C.; Liu, Y.-H.; Peng, S.-M.; Chiu, S.-H. Chem. Commun. 2007, 4122-4124. (d) Huang, Y.-L.; Lin, C.-F.; Cheng, P.-N.; Lai, C.-C.; Liu, Y.-H.; Peng, S.-M.; Chiu, S.-H. Tetrahedron Lett. 2008, 49, 1665-1669. (e) Chen, N.-C.; Lai, C.-C.; Liu, Y.-H.; Peng, S.-M.; Chiu, S.-H. Chem.-Eur. J. 2008, 14, 2904-2908.

(9) For this synthetic approach, please refer to: Linton, B. R.; Carr, A. J.; Orner, B. P.; Hamilton, A. D. J. Org. Chem. 2000, 65, 1566-1568.

(10) Connors, K. A. Binding Constants; Wiley: New York, 1987.

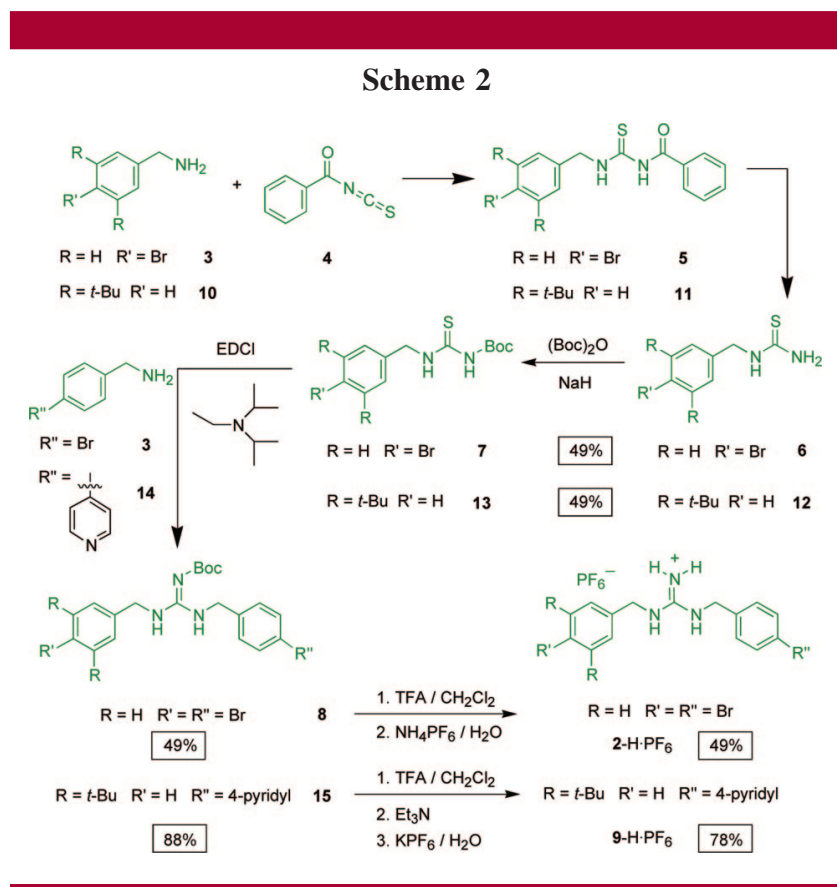

furnished the corresponding benzoyl thiourea $\mathbf{5}$, which we deacylated to provide the thiourea 6 . Boc protection of the $\mathrm{NH}_{2}$ group of $\mathbf{6}$ followed by an EDCI-activated substitution reaction with the amine $\mathbf{3}$ gave the dibromide $8 .{ }^{9}$ Removal of the Boc protecting group of $\mathbf{8}$ under acidic conditions, followed by anion exchange and column chromatography, provided $2-\mathrm{H} \cdot \mathrm{PF}_{6}$ as a white solid.

The ${ }^{1} \mathrm{H}$ NMR spectrum of an equimolar mixture of BPX26C6 and the threadlike guanidinium salt $2-\mathrm{H} \cdot \mathrm{PF}_{6}$ in $\mathrm{CDCl}_{3} / \mathrm{CD}_{3} \mathrm{CN}$ (10:1) at room temperature displays significant shifts in the positions of many of the signals relative to those for the free species (Figure 1). The upfield shifts for

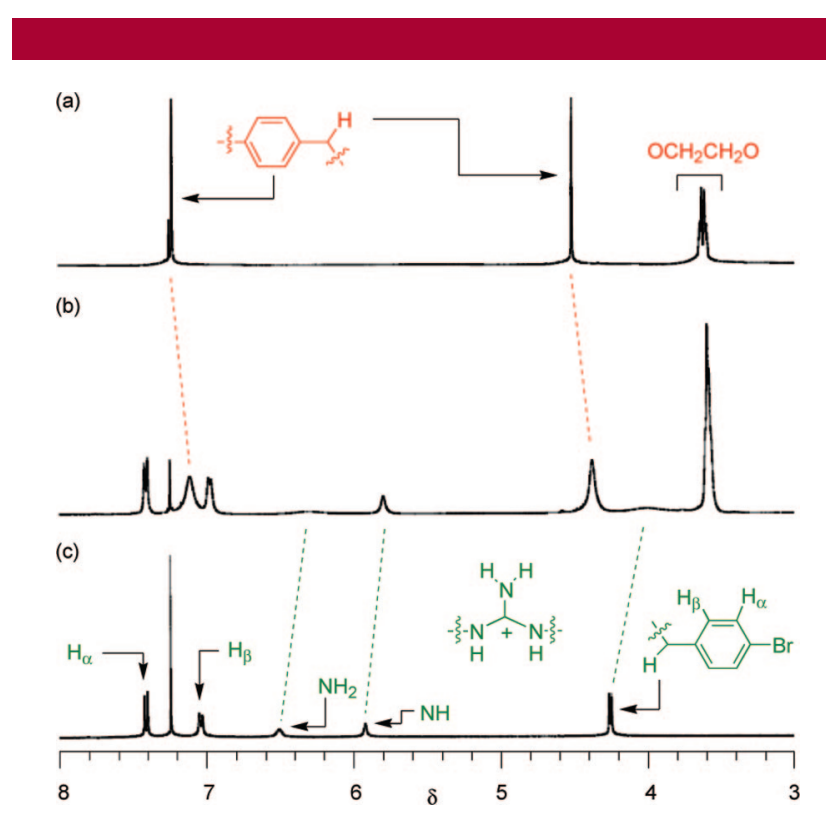

Figure 1. Partial ${ }^{1} \mathrm{H}$ NMR spectra $\left[400 \mathrm{MHz}, \mathrm{CDCl}_{3} / \mathrm{CD}_{3} \mathrm{CN}\right.$ (10: 1), $298 \mathrm{~K}$ ] of (a) BPX26C6, (b) an equimolar mixture of BPX26C6 and $2-\mathrm{H} \cdot \mathrm{PF}_{6}(20 \mathrm{mM})$, and (c) $2-\mathrm{H} \cdot \mathrm{PF}_{6}$. 
the signals of the xylyl and guanidinium protons of BPX26C6 and thread $2-\mathrm{H} \cdot \mathrm{PF}_{6}$, respectively, are consistent with the proposed geometry of the [2]pseudorotaxane [(BPX26C6つ2$\mathrm{H}) \cdot \mathrm{PF}_{6}$ ], in which the cationic guanidinium ion is located between the two xylyl groups of BPX26C6. Using ${ }^{1} \mathrm{H}$ NMR spectroscopic dilution experiments, we determined the association constant $\left(K_{\mathrm{a}}\right)$ for the interaction between the two species in $\mathrm{CDCl}_{3} / \mathrm{CD}_{3} \mathrm{CN}$ (10:1) to be $200 \pm 20 \mathrm{M}^{-1} .{ }^{10} \mathrm{We}$ observed negligible shifts for the signals in the ${ }^{1} \mathrm{H}$ NMR spectra of the same mixture in $\mathrm{CD}_{3} \mathrm{CN}, \mathrm{CD}_{3} \mathrm{NO}_{2}$, and $\mathrm{CDCl}_{3} /$ $\mathrm{CD}_{3} \mathrm{CN}(1: 1)$, relative to those of the free species, indicating that the interactions between the host and guest are very weak in moderately polar solvents.

To prove the existence of the [2]pseudorotaxane [(BPX$\left.26 \mathrm{C} 6 \supset 2-\mathrm{H}) \cdot \mathrm{PF}_{6}\right]$ in solution, we prepared a corresponding interlocked [2]rotaxane from a related complex formed between the threadlike guanidinium salt $9-\mathrm{H} \cdot \mathrm{PF}_{6}$ and BPX26C6. We synthesized $9-\mathrm{H} \cdot \mathrm{PF}_{6}$ from the amine $\mathbf{1 0}$ (Scheme 2) following a reaction pathway similar to that used to synthesize 2-H·PF . The reaction of 3,5-di-tert-butylbenzyl bromide (16), BPX26C6, and the threadlike guanidinium salt 9- $\mathrm{H} \cdot \mathrm{PF}_{6}$ (each $150 \mathrm{mM}$ ) in $\mathrm{CHCl}_{3} / \mathrm{CH}_{3} \mathrm{CN}$ (10:1) at room temperature gave the [2] rotaxane $\mathbf{1 7}-\mathrm{H} \cdot 2 \mathrm{PF}_{6}($ Scheme 3 ) and the dumbbell-shaped salt $18-\mathrm{H} \cdot 2 \mathrm{PF}_{6}$ in 18 and $52 \%$ yield, respectively, after ion exchange and column chromatography. ${ }^{11}$ This result confirmed that BPX26C6 encircles threadlike guanidinium ions in the form of [2]pseudorotaxanes in $\mathrm{CDCl}_{3} / \mathrm{CD}_{3} \mathrm{CN}$ (10:1) solution.

We suspected that $[\mathrm{N}-\mathrm{H} \cdots \mathrm{O}]$ hydrogen bonding between the BPX26C6 unit and the guanidinium station of the [2] rotaxane $17-\mathrm{H} \cdot 2 \mathrm{PF}_{6}$ would be more energetically favorable in $\mathrm{CDCl}_{3}$ than would be $\left[\mathrm{N}^{+} \mathrm{C}-\mathrm{H} \cdots \mathrm{O}\right]$ hydrogen bonding and any $\pi-\pi$ interactions between the BPX26C6 unit and the pyridinium station; i.e., BPX26C6 should encircle the guanidinium station in nonpolar solvents. The observation that only small shifts in the positions of the signals of the pyridinium unit $\left(\mathrm{H}_{\alpha}\right.$ and $\left.\mathrm{H}_{\beta}\right)$ and its adjacent $\mathrm{CH}_{2}$ group of the [2] rotaxane $17-\mathrm{H} \cdot 2 \mathrm{PF}_{6}$ in $\mathrm{CDCl}_{3}$ relative to those in the

(11) Data for [2] rotaxane $17-\mathrm{H} \cdot 2 \mathrm{PF}_{6}: \mathrm{mp} 105-106{ }^{\circ} \mathrm{C} ;{ }^{1} \mathrm{H}$ NMR $(400$ $\left.\mathrm{MHz}, \mathrm{CDCl}_{3}\right): \delta=1.34(\mathrm{~s}, 18 \mathrm{H}), 1.37(\mathrm{~s}, 18 \mathrm{H}), 3.65-3.69(\mathrm{~m}, 16 \mathrm{H})$, $3.80-3.98$ (br, 4H), 4.22-4.32 (m, 4H), 5.47 (br, 2H), $5.86(\mathrm{br}, 2 \mathrm{H})$, 6.22-6.38 (br, 2H), $6.92(\mathrm{~s}, 8 \mathrm{H}), 7.05(\mathrm{~s}, 2 \mathrm{H}), 7.26(\mathrm{~s}, 2 \mathrm{H}), 7.35-7.39$ (br, $2 \mathrm{H}), 7.40(\mathrm{~s}, 1 \mathrm{H}), 7.53(\mathrm{~s}, 1 \mathrm{H}), 7.80(\mathrm{~d}, J=8 \mathrm{~Hz}, 2 \mathrm{H}), 8.11-8.19(\mathrm{br}$, $2 \mathrm{H}), 8.57-8.61(\mathrm{br}, 2 \mathrm{H}) .{ }^{13} \mathrm{C}$ NMR $\left(100 \mathrm{MHz}, \mathrm{CDCl}_{3}\right): \delta=31.3,31.5$, $35.0,35.0,44.1,45.8,65.0,69.8,70.5,73.4,121.9,122.3,123.6,124.2$, 125.0, 127.9, 128.7, 128.8, 131.0, 132.5, 134.5, 136.7, 140.1, 143.6, 151.2, 152.5, 153.8, 155.4. HR-MS(ESI): $m / z$ calcd for $\left[17-\mathrm{H} \cdot \mathrm{PF}_{6}\right]^{+} \mathrm{C}_{67} \mathrm{H}_{92} \mathrm{~N}_{4} \mathrm{O}_{6} \mathrm{PF}_{6}$ 1193.6659, found 1193.6659; [17- $\mathrm{H}]^{2+} \mathrm{C}_{67} \mathrm{H}_{92} \mathrm{~N}_{4} \mathrm{O}_{6} 524.3509$, found 524.3508. Data for Dumbbell 18- $\mathrm{H} \cdot 2 \mathrm{PF}_{6}: \mathrm{mp} 112-115^{\circ} \mathrm{C}$. ${ }^{1} \mathrm{H}$ NMR $(400$ $\left.\mathrm{MHz}, \mathrm{CD}_{3} \mathrm{CN}\right): \delta=1.28(\mathrm{~s}, 18 \mathrm{H}), 1.32(\mathrm{~s}, 18 \mathrm{H}), 4.36(\mathrm{~d}, 6 \mathrm{~Hz}, 2 \mathrm{H}), 4.51$ $(\mathrm{d}, 6 \mathrm{~Hz}, 2 \mathrm{H}), 5.65(\mathrm{~s}, 2 \mathrm{H}), 6.25(\mathrm{br}, 2 \mathrm{H}), 6.75-6.78(\mathrm{~m}, 2 \mathrm{H}), 7.13(\mathrm{~s}$, $2 \mathrm{H}), 7.37(\mathrm{~s}, 2 \mathrm{H}), 7.40-7.44(\mathrm{~m}, 3 \mathrm{H}), 7.56(\mathrm{~s}, 1 \mathrm{H}), 7.86(\mathrm{~d}, J=8 \mathrm{~Hz}$, $2 \mathrm{H}), 8.22(\mathrm{~d}, J=7 \mathrm{~Hz}, 2 \mathrm{H}), 8.76(\mathrm{~d}, J=7 \mathrm{~Hz}, 2 \mathrm{H}) .{ }^{13} \mathrm{C} \mathrm{NMR}(100 \mathrm{MHz}$, $\left.\mathrm{CD}_{3} \mathrm{CN}\right): 31.4,31.5,35.4,35.6,44.9,46.0,64.9,121.7,122.2,123.7,124.2$, 125.4, 128.3, 128.6, 132.6, 133.3, 135.1, 140.8, 144.2, 151.4, 152.4, 155.8 (one signal is missing, possibly because of signal overlapping). HRMS(ESI): $m / z$ calcd for $\left[18-\mathrm{H}^{2} \cdot \mathrm{PF}_{6}\right]^{+} \mathrm{C}_{43} \mathrm{H}_{60} \mathrm{~N}_{4} \mathrm{PF}_{6} 777.4460$, found 777.4459 ; $[18-\mathrm{H}]^{2+} \mathrm{C}_{43} \mathrm{H}_{60} \mathrm{~N}_{4}$ 316.2409, found 316.2408.

(12) For other molecular switches that can be operated through changes in solvent polarity, see: (a) Lane, A. S.; Leigh, D. A.; Murphy, A. J. Am. Chem. Soc. 1997, 119, 11092-11093. (b) Ambrosi, G.; Dapporto, P.; Formica, M.; Fusi, V.; Giorgi, L.; Guerri, A.; Micheloni, M.; Paoli, P.; Pontellini, R.; Rossi, P. Chem.-Eur. J. 2003, 9, 800-810. (c) Chiang, P.T.; Cheng, P.-N.; Lin, C.-F.; Liu, Y.-H.; Lai, C.-C.; Peng, S.-M.; Chiu, S.-H. Chem.-Eur. J. 2006, 12, 865-876.
Scheme 3. Synthesis of the Molecular Switch $17-\mathrm{H} \cdot 2 \mathrm{PF}_{6}$

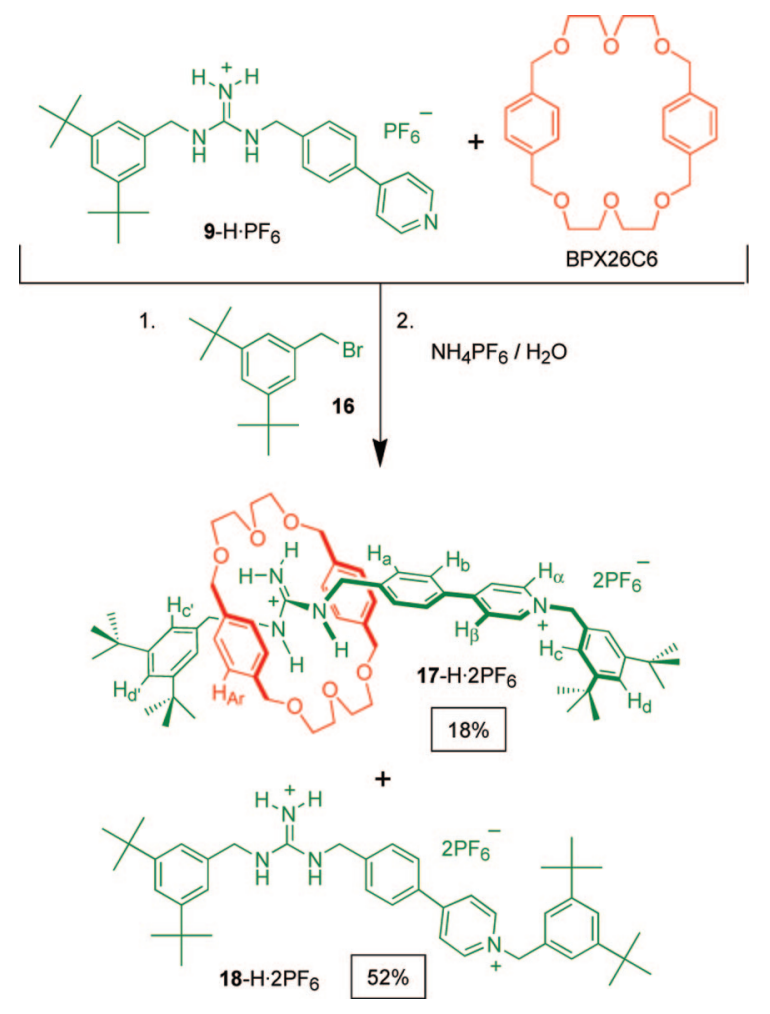

${ }^{1} \mathrm{H}$ NMR spectrum of the free dumbbell-shaped salt 18$\mathrm{H} \cdot 2 \mathrm{PF}_{6}$ under the same conditions and the lack of cross signals between these protons and the aromatic protons of the BPX26C6 unit in 2D NOSEY spectra supported that the macrocyclic component is not residue on the pyridinium station of the [2] rotaxane $\mathbf{1 7}-\mathrm{H} \cdot 2 \mathrm{PF}_{6}$ in $\mathrm{CDCl}_{3}$ (see the Supporting Information). The addition of $\mathrm{CD}_{3} \mathrm{CN}$ to the $\mathrm{CDCl}_{3}$ solution of the [2] rotaxane $\mathbf{1 7}-\mathrm{H} \cdot 2 \mathrm{PF}_{6}$ led to gradual, yet significant, upfield shifts in the positions of the signals of the pyridinium (and adjacent $\mathrm{CH}_{2}$ ) and xylyl protons in the ${ }^{1} \mathrm{H}$ NMR spectra (Figure 2). From a comparison with the spectra of the dumbbell-shaped salt $18-\mathrm{H} \cdot 2 \mathrm{PF}_{6}$ in these solvents and from the cross signals observed between the aromatic protons of the BPX26C6 unit and the pyridinium/ $\mathrm{CH}_{2}$ protons in the 2D NOSEY spectrum of $17-\mathrm{H} \cdot 2 \mathrm{PF}_{6}$ in $\mathrm{CD}_{3} \mathrm{CN}$, we infer that the BPX26C6 unit prefers to encircle the pyridinium station of this [2] rotaxane in relatively polar solvents. Thus, the [2] rotaxane $\mathbf{1 7}-\mathrm{H} \cdot 2 \mathrm{PF}_{6}$ behaves as a reversible molecular switch in which the BPX26C6 unit resides selectively on the guanidinium station in nonpolar solvents and on the pyridinium station in polar solvents. ${ }^{12}$

In addition to modifying the polarity of the solvent system, we expected that we could also operate the molecular switch by introducing, into a solution of the [2] rotaxane $17-\mathrm{H}^{2} 2 \mathrm{PF}_{6}$ in a nonpolar solvent, an anion that binds tightly to guanidinium ions, thereby forcing the BPX26C6 unit to migrate to the pyridinium station (Scheme 4). Indeed, after adding 3 equiv of tetra- $n$-butylammonium chloride $\left(\mathrm{Bu}_{4} \mathrm{NCl}\right)$ to a $\mathrm{CD}_{3} \mathrm{NO}_{2}$ solution of the [2] rotaxane $17-\mathrm{H} \cdot 2 \mathrm{PF}_{6}$, we observed significant upfield shifts of the signals of the 


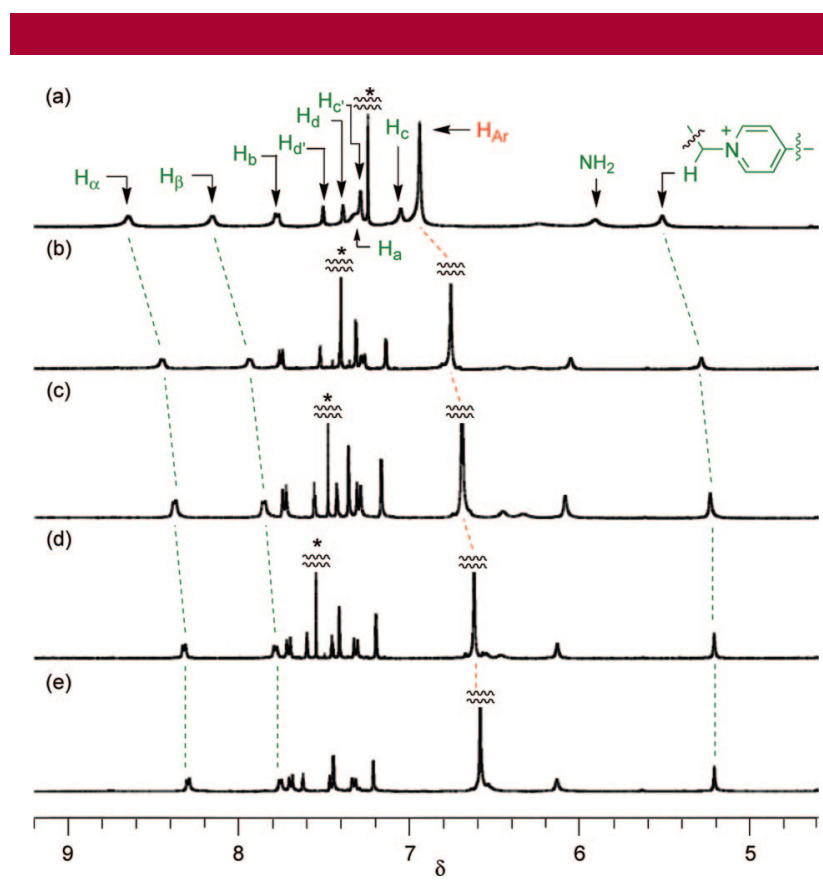

Figure 2. Partial ${ }^{1} \mathrm{H}$ NMR spectra $(400 \mathrm{MHz}, 298 \mathrm{~K})$ of the [2]rotaxane 17- $\mathrm{H} \cdot 2 \mathrm{PF}_{6}$ in (a) $\mathrm{CDCl}_{3}$, (b) $\mathrm{CDCl}_{3} / \mathrm{CD}_{3} \mathrm{CN}$ (2:1), (c) $\mathrm{CDCl}_{3} / \mathrm{CD}_{3} \mathrm{CN}$ (1:1), (d) $\mathrm{CDCl}_{3} / \mathrm{CD}_{3} \mathrm{CN}$ (1:4), and (e) $\mathrm{CD}_{3} \mathrm{CN}$.

Scheme 4. Using Anions to Operate the Molecular Switch $17-\mathrm{H} \cdot 2 \mathrm{PF}_{6}$

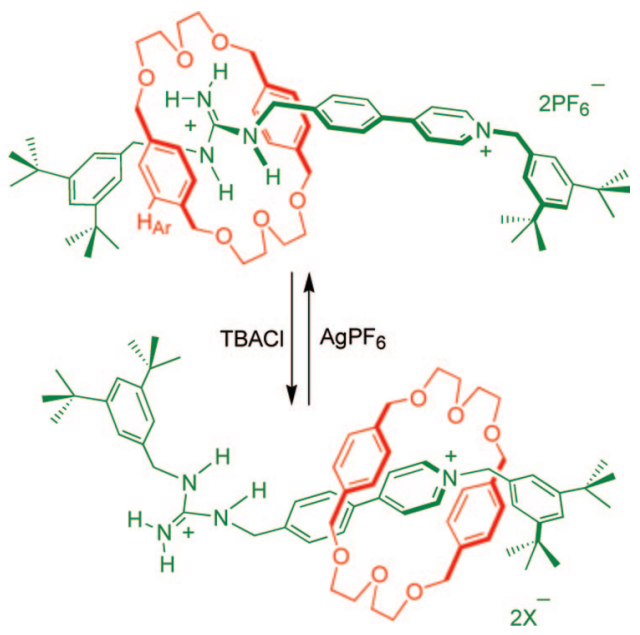

pyridinium protons $\left(\mathrm{H}_{\alpha}\right.$ and $\left.\mathrm{H}_{\beta}\right)$ and of the aromatic protons $\left(\mathrm{H}_{\mathrm{Ar}}\right)$ of the BPX26C6 unit, suggesting that the macrocyclic component now resided on the pyridinium station. The migration of the BPX26C6 unit from the guanidinium to the pyridinium station upon the addition of the chloride anions was supported by 2D NOSEY spectra, which revealed cross peaks between the signals of the aromatic/ethylene glycol protons of the BPX26C6 moiety and the pyridinium protons after we had added $\mathrm{Bu}_{4} \mathrm{NCl}$ into the solution, but not before. Subsequent addition of 3 equiv of $\mathrm{AgPF}_{6}-$ to remove the chloride anions from solution through precipitation of $\mathrm{AgCl}$-gave a spectrum (Figure 3e) similar to that of the

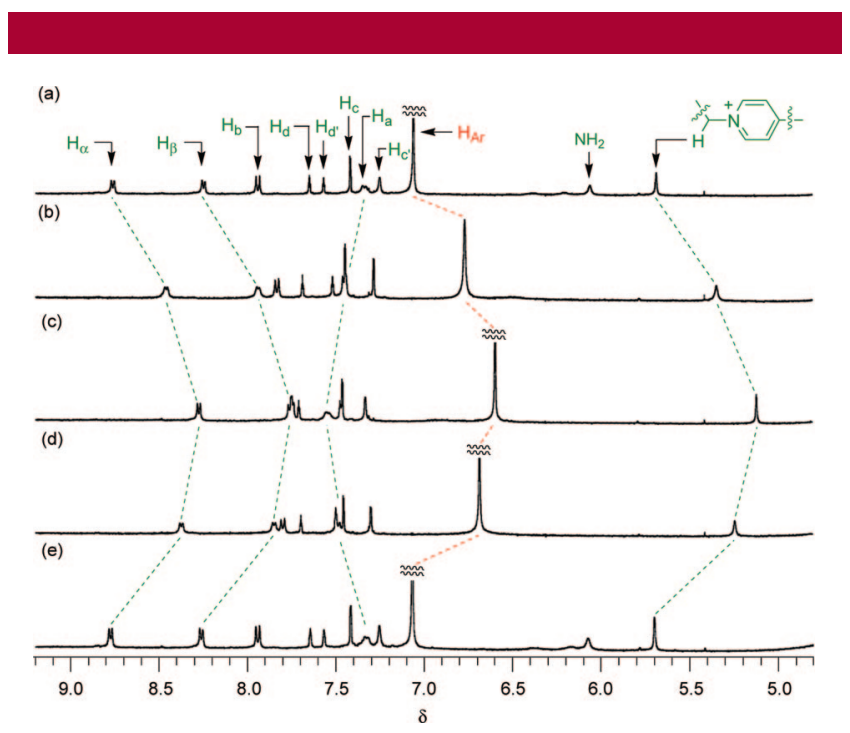

Figure 3. Partial ${ }^{1} \mathrm{H}$ NMR spectra $\left(400 \mathrm{MHz}, \mathrm{CD}_{3} \mathrm{NO}_{2}, 298 \mathrm{~K}\right.$ ) of (a) the molecular switch $\mathbf{1 7}-\mathrm{H} \cdot 2 \mathrm{PF}_{6}$, (b) the mixture obtained after adding $\mathrm{Bu}_{4} \mathrm{NCl}$ (1 equiv) to the solution in (a), (c) the mixture obtained after adding $\mathrm{Bu}_{4} \mathrm{NCl}$ (2 equiv) to the solution in (b), (d) the mixture obtained after adding $\mathrm{AgPF}_{6}$ (1 equiv) to the solution in (c), and (e) the mixture obtained after adding $\operatorname{AgPF}_{6}$ (2 equiv) to the solution in $(\mathrm{d})$.

original [2] rotaxane $17-\mathrm{H} \cdot 2 \mathrm{PF}_{6}$, suggesting that the BPX26C6 unit had migrated back to the guanidinium station. Thus, reversible switching of the BPX26C6 unit between the guanidinium and pyridinium stations of the [2] rotaxane 17$\mathrm{H} \cdot 2 \mathrm{PF}_{6}$ was possible in situ through the addition and removal of chloride anions. Indeed, we also operated this unique anion-controllable molecular switch through the addition and removal of bromide and acetate anions (see the Supporting Information).

We have demonstrated that guanidinium ions can thread through the cavity of BPX26C6 to form [2]pseudorotaxanelike complexes in low-polarity solvents. A [2]rotaxane derived from this new recognition system functions as a molecular switch, in which translational movement of the macrocyclic component can be controlled two ways: through changes in solvent polarity and through exchange of the counteranions.

Acknowledgment. We thank the National Science Council (Taiwan) for financial support (NSC-95-2113-M-002-016MY3).

Supporting Information Available: Synthetic procedures and characterization data for the [2] rotaxane $17-\mathrm{H} \cdot 2 \mathrm{PF}_{6}$. This material is available free of charge via the Internet at http://pubs.acs.org.

OL802638K 